\title{
Relationship Between Mechanical Properties of Lead-Free Solders and Their Heat Treatment Parameters
}

\author{
A. Klasik, N. Sobczak, K. Pietrzak, K. Makowska, A. Wojciechowski, A. Kudyba, and E. Sienicki
}

(Submitted October 27, 2011)

\begin{abstract}
The research was undertaken to establish mechanical properties of as-cast and heat-treated $\mathrm{Sn}$-Zn-based alloys of binary and ternary systems as candidates for lead (Pb)-free solder materials for high-temperature applications. The heat treatment of as-cast alloys was made under different combinations of processing parameters $\left(168 \mathrm{~h} / 50{ }^{\circ} \mathrm{C}, 42 \mathrm{~h} / 80{ }^{\circ} \mathrm{C}\right.$, and $\left.24 \mathrm{~h} / 110{ }^{\circ} \mathrm{C}\right)$. The systematic study of structure-property relationships in $\mathrm{Sn}-\mathrm{Zn}, \mathrm{Sn}-\mathrm{Zn}-\mathrm{Ag}$, and $\mathrm{Sn}-\mathrm{Zn}-\mathrm{Cu}$ alloys containing the same amount of $\mathrm{Zn}(4.5,9,13.5$ wt.\%) and $1 \mathrm{wt} . \%$ of either $\mathrm{Ag}$ or $\mathrm{Cu}$ was conducted to identify the effects of chemical composition and heat treatment processing parameters on the alloy microstructure and mechanical behavior. Structural characterization was made using optical microscopy and scanning electron microscopy techniques coupled with EDS analysis. Mechanical properties (initial Young's modulus $E$, ultimate tensile strength UTS, elastic limit $R_{0.05}$, yield point $R_{0.2}$, elongation $A_{5}$, and necking $Z$ ) were determined by means of static tensile tests. All the examined Sn-Zn-based alloys have attractive combination of mechanical characteristics, especially tensile strength, having values higher than that of common leaded solders and their substitutes of Pb-free SAC family. The results obtained demonstrate that the $\mathrm{Sn}-\mathrm{Zn}$-based alloys present competitive $\mathbf{P b}$-free solder candidates for high-temperature applications.
\end{abstract}

Keywords mechanical tests, microstructure, $\mathrm{Pb}-$ free, $\mathrm{Sn}-\mathrm{Zn}, \mathrm{Sn}-$ $\mathrm{Zn}-\mathrm{Ag}, \mathrm{Sn}-\mathrm{Zn}-\mathrm{Cu}$

\section{Introduction}

In response to serious health and environmental safety problems related with the use of lead, regulatory actions have been taken in many countries to eliminate this element from solder materials for electronic devices (Ref 1). Numerous efforts has been made to develop lead $(\mathrm{Pb})$-free solders that are intended to be an alternative for the long-established family of Pb-containing solder alloys (Ref 1-3). Due to a low cost coupled with melting point close to that of conventional $\mathrm{Sn}-\mathrm{Pb}$ solders, the $\mathrm{Sn}-\mathrm{Zn}$-based alloys are recognized as a possible replacement for high $\mathrm{Pb}$-containing solders that are still commonly used, particularly for high-temperature applications (Ref 1, 4-8). Therefore, studies on factors affecting material properties of these alloys are underway (Ref 2-6). Considering

This article is an invited submission to JMEP selected from presentations at the Symposia "Wetting, soldering and brazing" and "Diffusion bonding and characterization" belonging to the Topic "Joining" at the European Congress and Exhibition on Advanced Materials and Processes (EUROMAT 2011), held September 12-15, 2011, in Montpellier, France, and has been expanded from the original presentation.

A. Klasik, N. Sobczak, K. Pietrzak, K. Makowska, A. Wojciechowski, and E. Sienicki, Motor Transport Institute - Centre for Material Testing, Jagiellonska 80, 03-301 Warsaw, Poland; and A. Kudyba, Foundry Research Institute Centre for High-temperature Studies, Zakopianska 73, 30-418 Cracow, Poland. Contact e-mail: adam.klasik@its.waw.pl. working conditions of most electronic devices exposed to high temperature and/or thermal cycling, information on the influence of temperature on microstructure stability, and change in mechanical characteristics of bulk solder alloys is of practical importance. For example, alloying $\mathrm{Sn}-\mathrm{Zn}$ alloys with $1 \mathrm{wt}$ \% $\mathrm{Bi}$ enhanced the solid solution effect and raised the tensile strength of both the as-cast and the annealed alloys (Ref 8).

This research was carried out to establish mechanical properties of Sn-based alloys from the binary Sn-Zn and ternary $\mathrm{Sn}-\mathrm{Zn}-\mathrm{Cu}$ and $\mathrm{Sn}-\mathrm{Zn}-\mathrm{Ag}$ systems exposed to high temperature.

The systematic studies of structure-property relationships were carried out on as-cast and heat-treated alloys containing various amounts of alloying additions to identify the effects of the alloy chemical composition and temperature exposure on microstructure variations and mechanical behavior of $\mathrm{Sn}-\mathrm{Zn}$-based alloys.

\section{Materials and Testing}

Three groups of Sn-Zn-based alloys were examined in this study, i.e.,

(1) Sn-Zn binary alloys containing 4.5, 9.0, and $13.5 \mathrm{Zn}$ (wt.\%), i.e., SnZn4.5, SnZn9, and SnZn13.5,

(2) ternary alloys of Sn-Zn-Cu system containing the same amounts of $\mathrm{Zn}$ as in binary $\mathrm{Sn}-\mathrm{Zn}$ alloys and additionally 1 wt.\% Cu (SnZn4.5Cu1, SnZn9Cu1, and SnZn13.5Cu1),

(3) ternary alloys of $\mathrm{Sn}-\mathrm{Zn}-\mathrm{Ag}$ system in which $\mathrm{Cu}$ was replaced by 1 wt.\% Ag (SnZn4.5Ag1, SnZn9Ag1, and SnZn13.5Ag1).

The alloys were made from pure metals of $99.9 \%$ purity by melting in a graphite crucible under Ar cover and cast at about $50{ }^{\circ} \mathrm{C}$ above liquidus into a graphite die allowing ready samples to be produced for mechanical testing. 
The as-cast samples were heat treated in air using the following different combinations of time-temperature parameters: $168 \mathrm{~h} / 50{ }^{\circ} \mathrm{C}, 42 \mathrm{~h} / 80{ }^{\circ} \mathrm{C}$, and $24 \mathrm{~h} / 110{ }^{\circ} \mathrm{C}$.

Static tensile tests using INSTRON 8802 machine were done for determination of a set of room temperature mechanical properties of both as-cast and heat-treated alloys. All the tests were done using unmachined samples and the same steady tension rate of $0.2 \mathrm{~mm} / \mathrm{s}$. The following mechanical characteristics were determined: initial Young's modulus $E$, ultimate tensile strength $R_{\mathrm{m}}$, elastic limit $R_{0.05}$, yield point $R_{0.2}$, elongation $A_{5}$, and necking $Z$.

Qualitative microstructure assessment of all the samples was carried out by means of light microscopy (Olympus PMG3) using conventional light, polarized light, and phase contrast techniques. More detailed structural characterization was done by means of scanning electron microscopy (SEM) using a JSM 6360LA microscope equipped with energy dispersive spectrometer (EDS) of for local chemical analysis and phase identification.

\section{Results and Discussion}

\subsection{Microstructure Examination}

Microstructure of the as-cast binary Sn-Zn alloys (Fig. 1) is composed of the $\mathrm{Sn}-\mathrm{Zn}$ eutectic and primary precipitates of either a $\beta$-Sn-rich solid solution (white) or Zn-rich phase (dark). Low Zn-containing SnZn4.5 alloy has typical hypoeutectic structure with eutectic located in the interdendritic regions between large $\beta$-Sn grains (Fig. 1a). Microstructure of the ascast $\mathrm{SnZn} 9$ alloy of near-eutectic composition ( $\mathrm{Sn}-\mathrm{Zn}$ eutectic contains 8.9 wt.\% Zn, Ref 1) is composed of the Sn-Zn eutectic grains. However, a small amount of the Zn-rich phase has also been noted in as-cast alloy in the form of small needle-like precipitates (Fig. 1b). Similar to the as-cast SnZn9 alloy, the main constituent of the as-cast SnZn13.5 alloy of hypereutectic composition is the $\mathrm{Sn}-\mathrm{Zn}$ eutectic, the grains of which are dispersed with large needle-shaped Zn-rich particles (Fig. 1c).

Microstructure and especially phase composition of the ascast ternary $\mathrm{Sn}-\mathrm{Zn}-\mathrm{Cu}$ and $\mathrm{Sn}-\mathrm{Zn}-\mathrm{Ag}$ alloys strongly depend on their chemical composition and type of alloying addition used. It is predominantly well evidenced by the effect of $\mathrm{Cu}$ and $\mathrm{Ag}$ additions on the amount and morphology of $\mathrm{Zn}$-rich needleshaped precipitates formed in as-cast ternary alloys.

Introduction of $1 \mathrm{wt} . \% \mathrm{Cu}$ almost completely eliminates the formation of $\mathrm{Zn}$-rich needle-like precipitates in the alloys containing 4.5-13.5 wt.\% Zn (Fig. 3). As-cast SnZn4.5Cu1 alloy is composed of $\beta-\mathrm{Sn}(\mathrm{Zn}, \mathrm{Cu})$ grains surrounded by a small amount of Sn-Zn eutectic. Compared to binary SnZn4.5 alloy, these grains are much smaller while the amount of eutectic is reduced and it is more dispersed. Only occasionally small precipitates of the $\mathrm{Cu}_{5} \mathrm{Zn}_{8}$ phase are also noted (Fig. 2a). An increase in $\mathrm{Zn}$ content in the $\mathrm{Sn}-\mathrm{Zn}-\mathrm{Cu}$ alloy up to $9 \mathrm{wt} . \%$ reduces the amount of $\beta-\mathrm{Sn}(\mathrm{Zn}, \mathrm{Cu})$ phase increasing simultaneously the amount of both $\mathrm{Sn}-\mathrm{Zn}$ eutectic and $\mathrm{Cu}_{5} \mathrm{Zn}_{8}$ precipitates (Fig. 2b). As-cast $\mathrm{SnZn} 13.5 \mathrm{Cu} 1$ alloy is mainly composed of eutectic matrix with increased amount of $\mathrm{Cu}_{5} \mathrm{Zn}_{8}$ precipitates (Fig. 2c).

In all the examined as-cast ternary $\mathrm{Sn}-\mathrm{Zn}$-Ag alloys (Fig. 3a to c), the precipitates of $\mathrm{AgZn}_{3}$ intermetallic compound are formed instead of the $\mathrm{Cu}_{5} \mathrm{Zn}_{8}$ ones noted in the as-cast $\mathrm{Sn}-\mathrm{Zn}-\mathrm{Cu}$ alloys

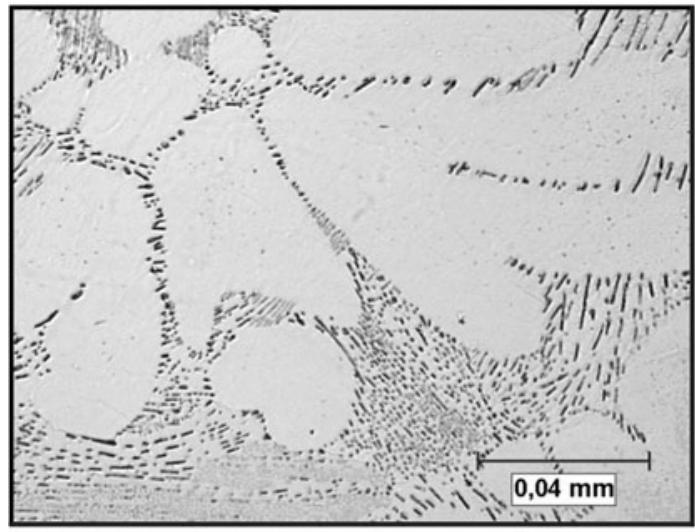

(a)

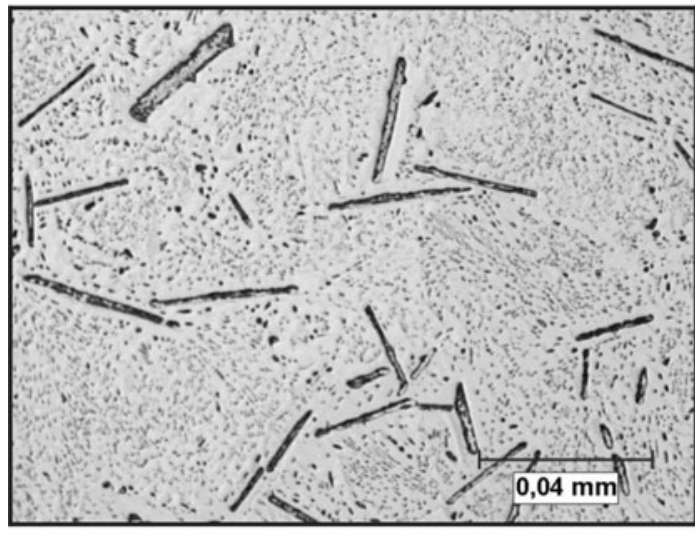

(b)

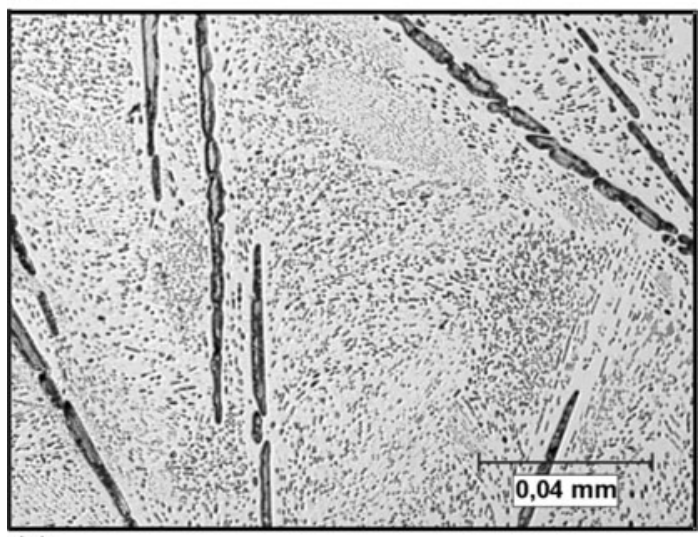

(c)

Fig. 1 Microstructure of as-cast binary $\mathrm{Sn}-\mathrm{Zn}$ alloys: (a) $\mathrm{SnZn} 4.5$, (b) SnZn9, and (c) SnZn13.5

(Fig. 3). Depending on Zn content, they have either a regular shape (Fig. 3a, b) or dendrite-like morphology (Fig. 3c). However, contrary to the as-cast $\mathrm{Sn}-\mathrm{Zn}-\mathrm{Cu}$ alloys, an addition of 1 wt. $\%$ Ag does dot suppress the formation of $\mathrm{Zn}$-rich phase of which fine needle-like precipitates are well evidenced in the SnZn13.5Ag1 alloy (Fig. 3c). Compared with the as-cast SnZn13.5 alloy, the amount of these precipitates is significantly reduced while their size is by a few orders of magnitude smaller.

Heat treatment made for selected combination of timetemperature processing parameters $\left(168 \mathrm{~h} / 50{ }^{\circ} \mathrm{C}, 42 \mathrm{~h} / 80{ }^{\circ} \mathrm{C}\right.$, and $24 \mathrm{~h} / 110^{\circ} \mathrm{C}$ ) has considerable effect on microstructure, particularly for binary Sn-Zn alloys (Fig. 4). For SnZn4.5 alloy (Fig. 4a to c), annealing at $50{ }^{\circ} \mathrm{C}$ results in coarsening of the 


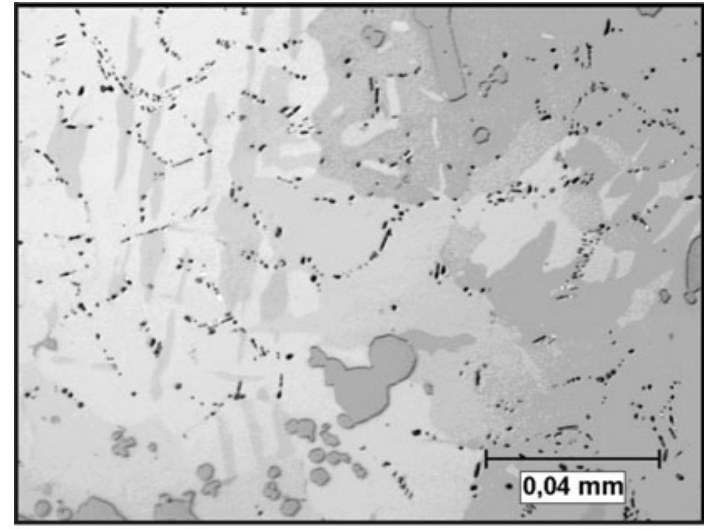

(a)

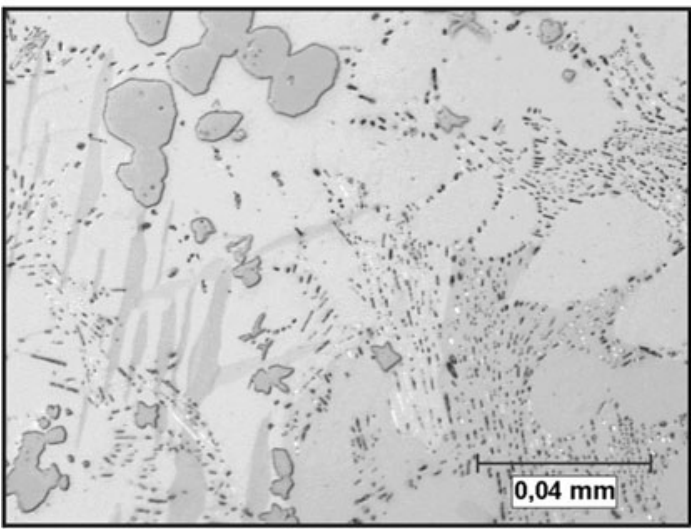

(b)

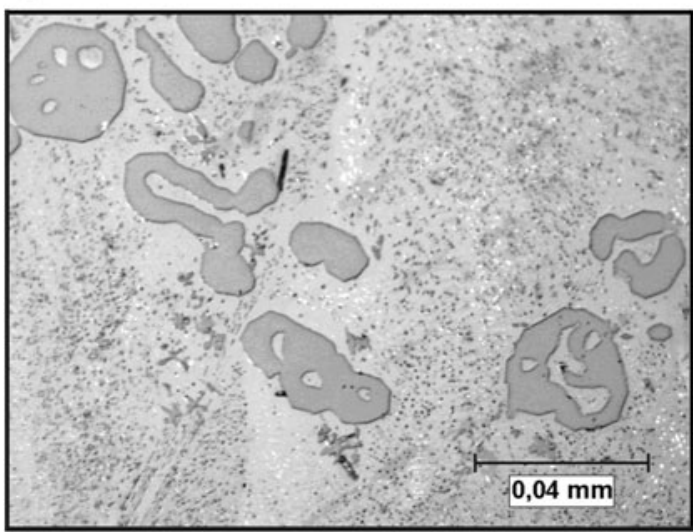

(c)

Fig. 2 Microstructure of as-cast ternary $\mathrm{Sn}-\mathrm{Zn}-\mathrm{Cu}$ alloys: (a) SnZn4.5Cu1, (b) SnZn9Cu1, and (c) SnZn13.5Cu1

Sn-Zn eutectic while further increase in temperature causes an increase in its amount together with decrease in the size of $\beta$-Sn-rich grains. For SnZn9 alloy (Fig. 4d to f), heat treatment contributes to both coarsening of the $\mathrm{Sn}-\mathrm{Zn}$ eutectic and gradual disappearance of $\mathrm{Zn}$-rich needle-like precipitates, particularly well distinguished with increase of annealing temperature. Similar effect was noted also in the SnZn13.5 alloy, showing less needle-shaped precipitates of much smaller size for the Zn-rich phase.

An addition of 1 wt. $\% \mathrm{Cu}$ coupled with application of heat treatment results in significant reduction in the eutectic amount and this effect becomes more pronounced with increase in annealing temperature (Fig. 5 to 7). After heat treatment at

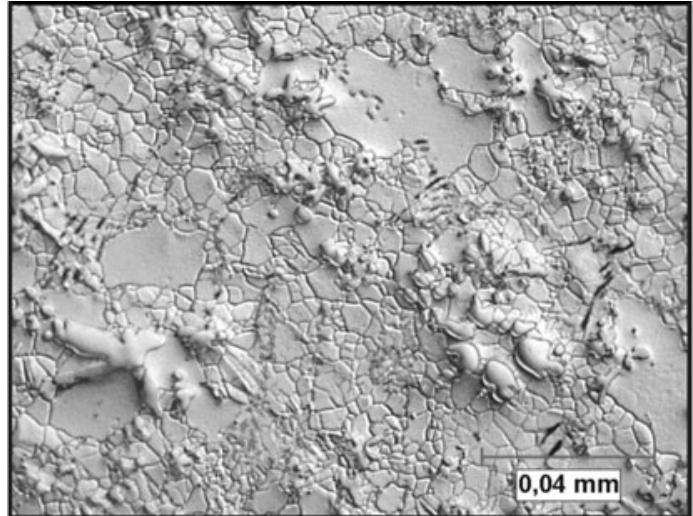

(a)

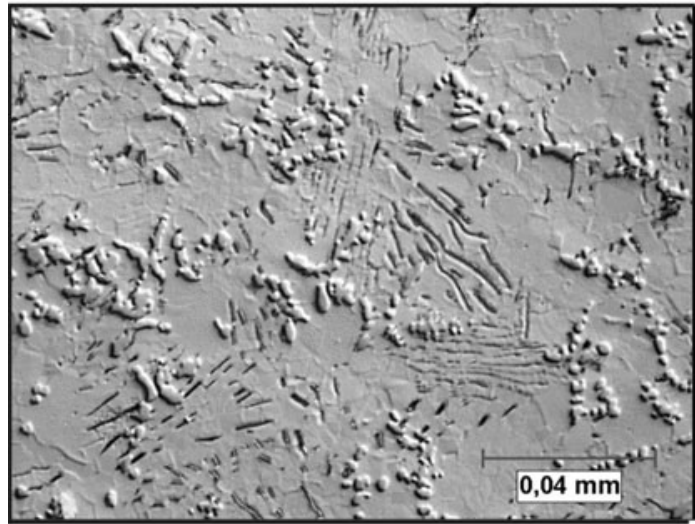

(b)

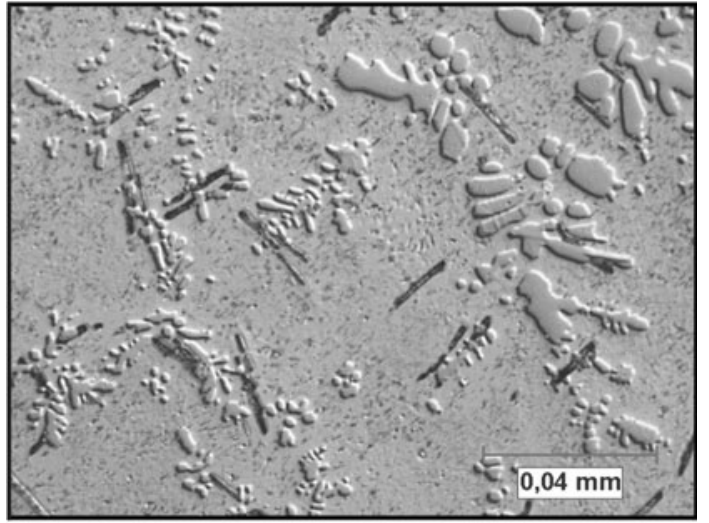

(c)

Fig. 3 Microstructure of as-cast ternary $\mathrm{Sn}-\mathrm{Zn}-\mathrm{Ag}$ alloys: (a) SnZn4.5Ag1, (b) SnZn9Ag1, and (c) SnZn13.5Ag1

$50{ }^{\circ} \mathrm{C}$, contrary to the $\mathrm{SnZn} 4.4$ alloy, the $\mathrm{SnZn} 4.4 \mathrm{Cu} 1$ alloy has only a small amount of eutectic constituent and its structure is coarser (Fig. 5a). With increase in annealing temperature up to $80{ }^{\circ} \mathrm{C}$, the eutectic becomes very fine while its amount is significantly reduced since it is evidenced only in very small regions at the grain boundaries (Fig. 5b). After heat treatment at the highest temperature of $110{ }^{\circ} \mathrm{C}$, the eutectic disappears completely (Fig. 5c). As shown in Fig. 6, annealing of the SnZn9Cu1 alloy results in coarsening of all the structural constituents but the strongest effect is noted for $\beta$-Sn-rich phase at the highest temperature of heat treatment (Fig. 6c). The same

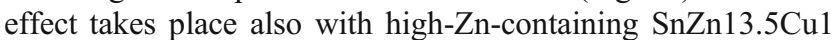
alloy although it is less pronounced than other alloys (Fig. 7). 


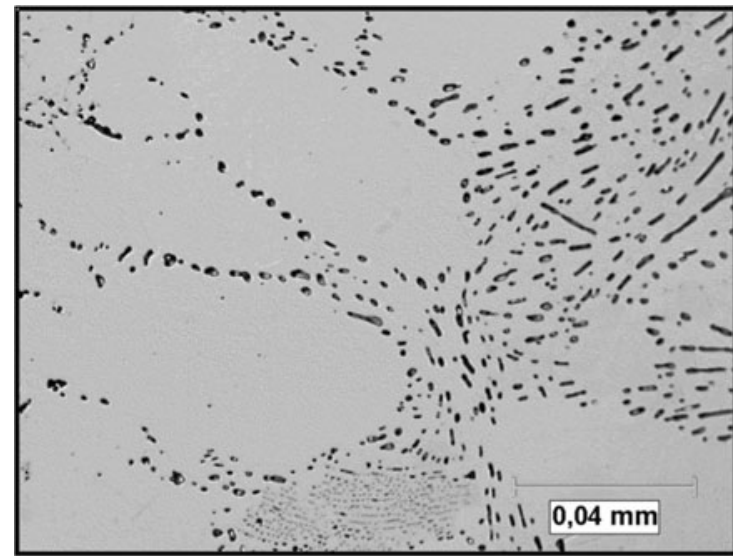

(a)

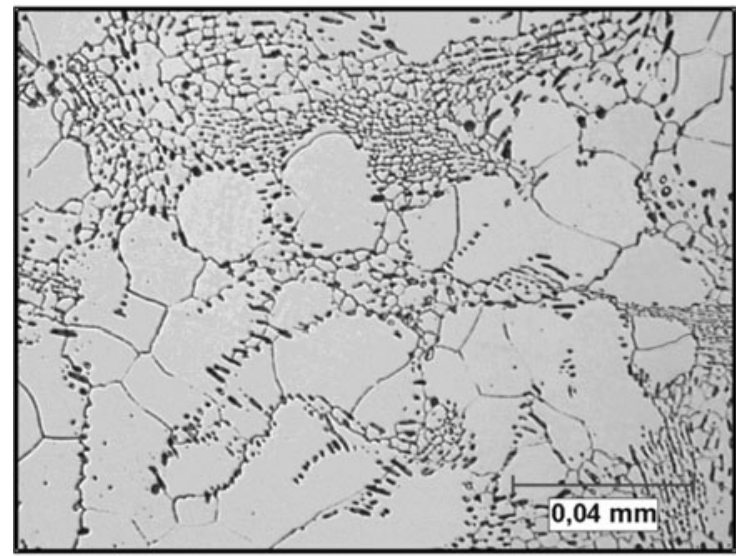

(b)

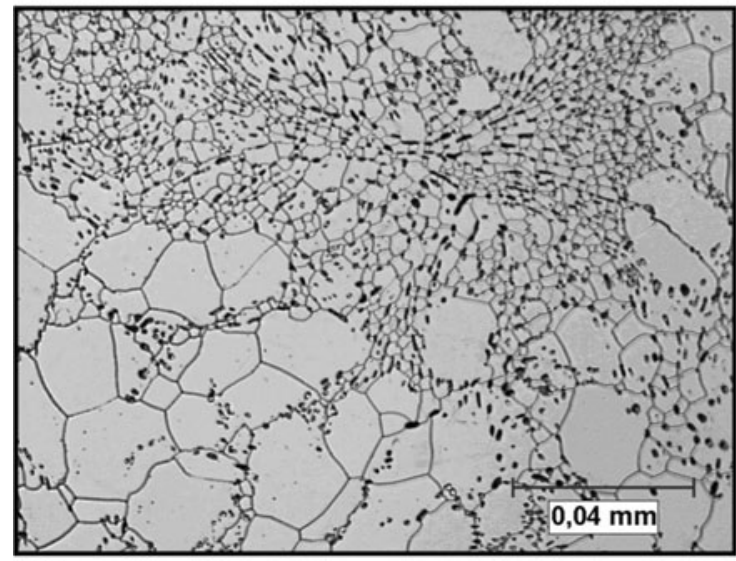

(c)

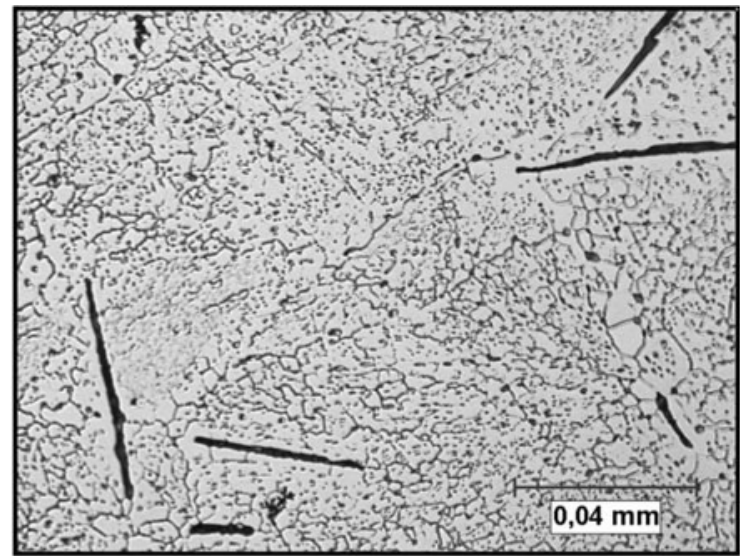

(d)

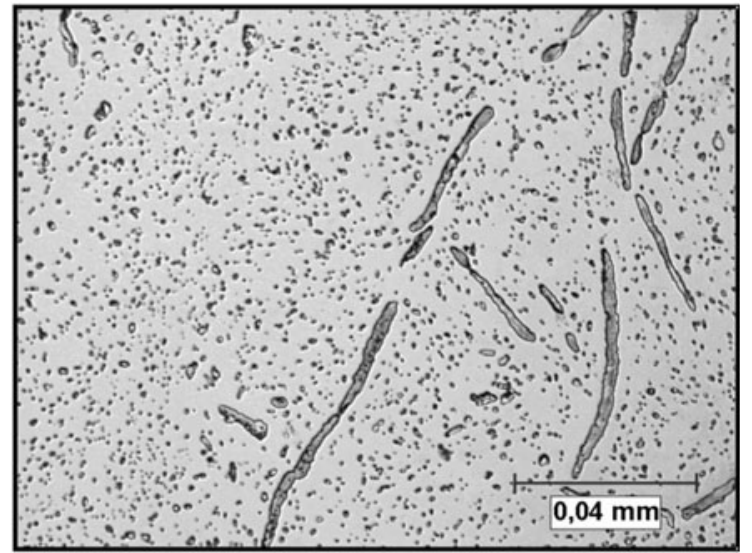

(e)

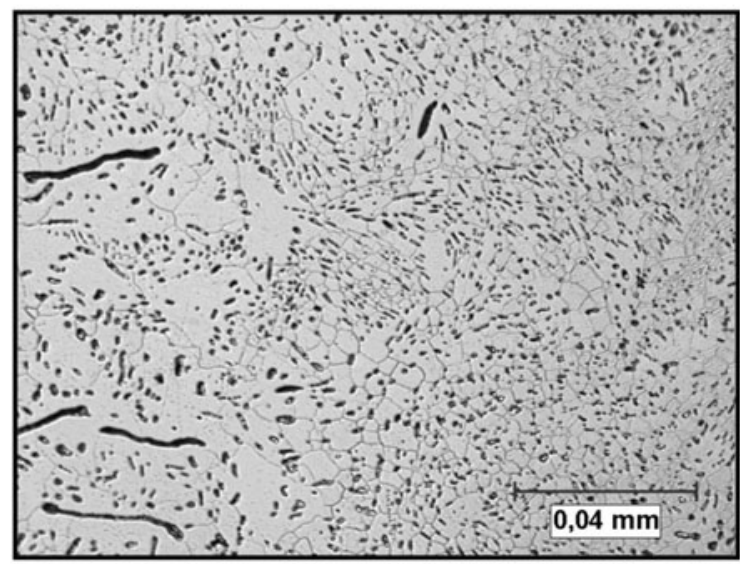

(f)

Fig. 4 Microstructure of heat treated binary Sn-Zn alloys (a, d $168 \mathrm{~h} / 50{ }^{\circ} \mathrm{C}$; b, e $42 \mathrm{~h} / 80{ }^{\circ} \mathrm{C}$; c, f $\left.24 \mathrm{~h} / 110{ }^{\circ} \mathrm{C}\right):(\mathrm{a}-\mathrm{c}) \mathrm{SnZn} 4.5$, (d-f) SnZn9

Moreover, contrary to as-cast condition, in heat-treated

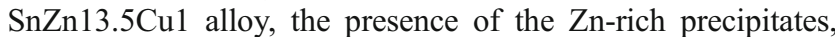
whose amount increases with increase in annealing temperature, is clearly evidenced.

Heat treatment of Sn-Zn-Ag alloys results mainly in coarsening of second phase precipitates, i.e., the $\beta$-Sn-rich phase in low Zn-containing SnZn4.5Ag1 alloy and the $\mathrm{AgZn}_{3}$ phase in SnZn9Ag1 and SnZn13.5Ag1 alloys (Fig. 8 to 10). This effect is accompanied by a change in the amounts of the alloy constituents due to an increase in annealing temperature. For SnZnAg1 alloy, higher temperature results in the reduction of eutectic fraction coupled with a significant refining effect for the $\mathrm{AgZn}$, precipitates (Fig. 8). On the contrary, the heat-treated SnZn9Ag1 alloy has numerous fine $\mathrm{AgZn}_{3}$ precipitates only after annealing at $50{ }^{\circ} \mathrm{C}$ but their number is significantly reduced and they become at least a few times bigger after heat treatment at 80 and $100{ }^{\circ} \mathrm{C}$ (Fig. 9). Additionally, an increase in annealing temperature results in an increase in the volume and size of the Sn-rich crystals. Coarsening of the $\mathrm{AgZn}_{3}$ precipitates during heat treatment of SnZn13.5Ag1 alloy is accompanied by complete disappearance of its dendritelike structure with increase in annealing temperature (Fig. 10), as compared to as-cast alloy (Fig. 1c). 


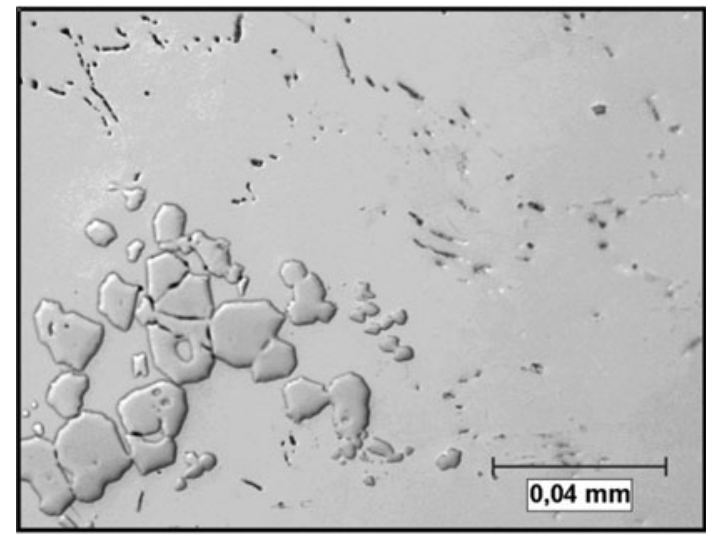

(a)

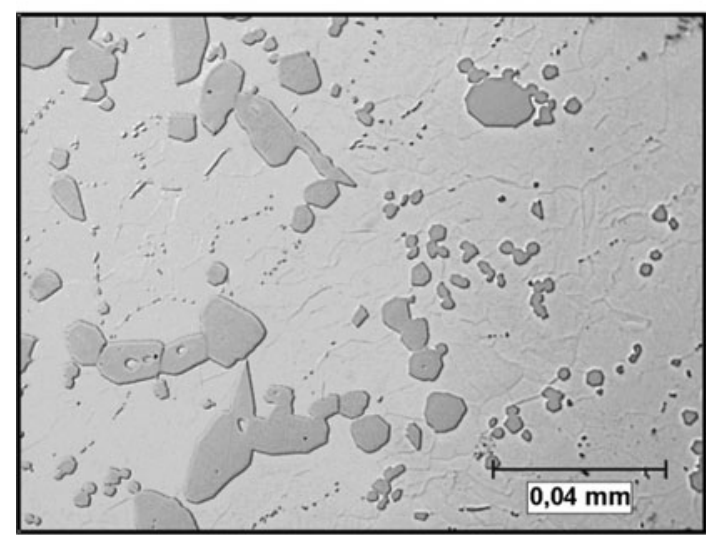

(b)

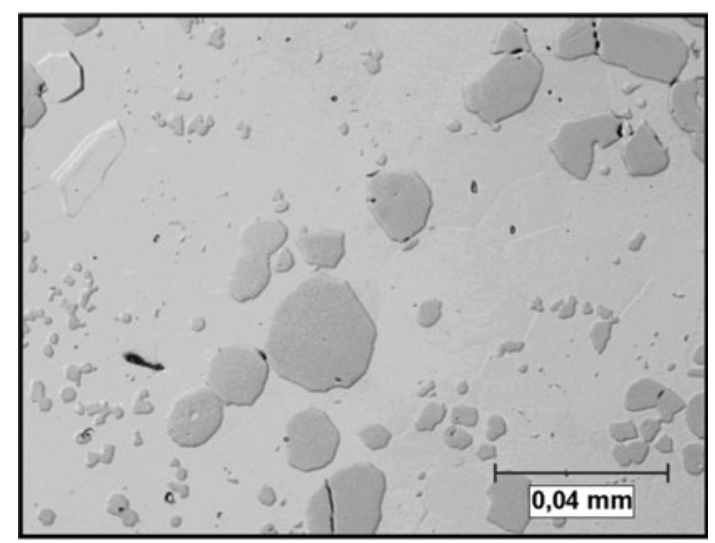

(c)

Fig. 5 Microstructure of heat-treated SnZn4.5Cu1 alloy: (a) $168 \mathrm{~h} /$ $50{ }^{\circ} \mathrm{C}$, (b) $42 \mathrm{~h} / 80{ }^{\circ} \mathrm{C}$, and (c) $24 \mathrm{~h} / 110^{\circ} \mathrm{C}$

\subsection{Mechanical Tests}

The results of static tensile tests of as-cast and heat-treated $\mathrm{Sn}-\mathrm{Zn}, \mathrm{Sn}-\mathrm{Zn}-\mathrm{Ag}$, and $\mathrm{Sn}-\mathrm{Zn}-\mathrm{Cu}$ alloys are collected in Table 1, 2, and 3, respectively. Experimental data on as-cast alloys show a strong effect of the alloy chemical composition on all the examined mechanical characteristics.

The best combination of mechanical properties was recorded for the $\mathrm{Sn}-\mathrm{Zn} 9$ alloy showing $R_{\mathrm{m}}-88 \mathrm{MPa}, R_{0.05}-72 \mathrm{MPa}$, $R_{0.2}-79 \mathrm{MPa}, E-38 \mathrm{GPa}, A_{5}-41 \%$, and $Z-84 \%$. The highest tensile strength of this alloy of a near-eutectic composition is contributed to its uniform fibrous-like structure of the $\mathrm{Sn}-\mathrm{Zn}$ eutectic coupled with a lack of coarse primary

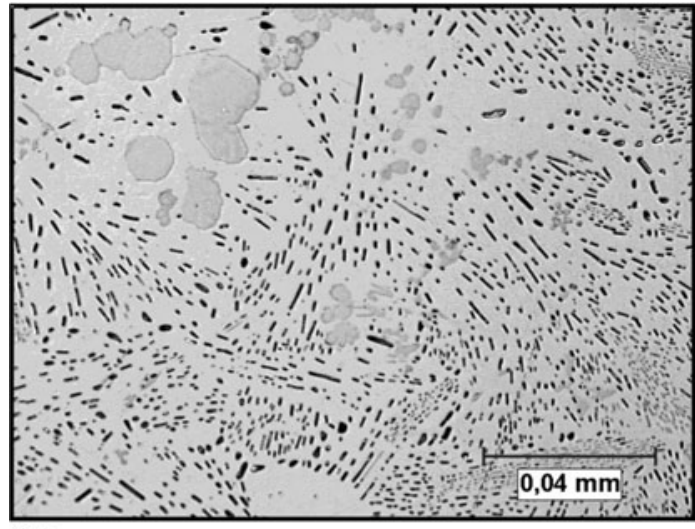

(a)

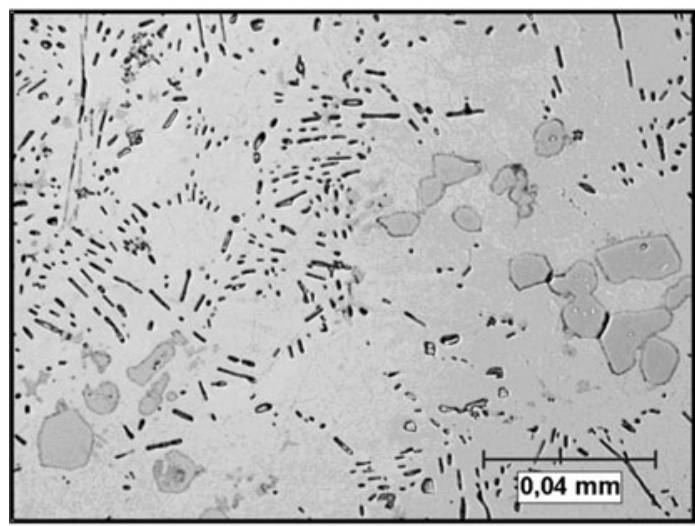

(b)

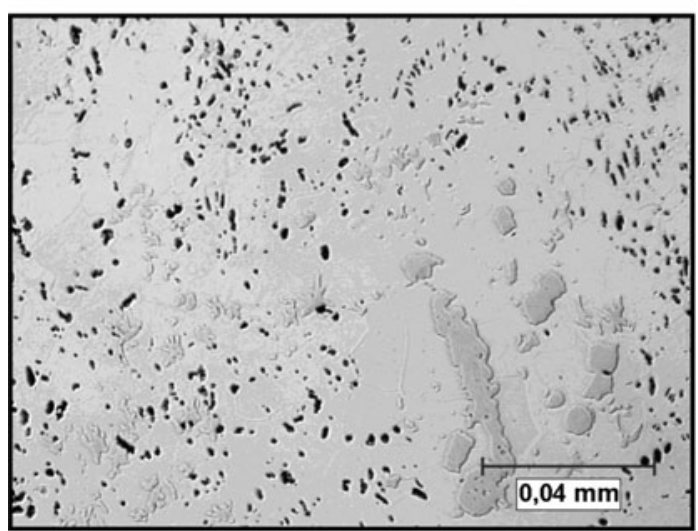

(c)

Fig. 6 Microstructure of heat-treated SnZn9Cu1 alloy: (a) $168 \mathrm{~h} /$ $50{ }^{\circ} \mathrm{C}$, (b) $42 \mathrm{~h} / 80{ }^{\circ} \mathrm{C}$, and (c) $24 \mathrm{~h} / 110^{\circ} \mathrm{C}$

Sn- or Zn-rich precipitates. This fact was suggested to be an experimental evidence that the microstructure rather than the relative content of $\mathrm{Sn}$ - and $\mathrm{Zn}$-rich phases governs the mechanical behavior of the alloy (Ref 8). As a consequence, heat treatment of the SnZn9 alloy resulting in coarsening of its microstructure (Fig. 1b, 4d to f) causes also the reduction in mechanical strength $R_{\mathrm{m}}$ (Table 1). The higher is the annealing temperature, the more are the significant microstructural changes and this effect on mechanical strength of the SnZn9 alloy becomes more noticeable.

Conversely, for hypoeutectic and hypereutectic alloys, the mechanical strength slightly increases with annealing temperature resulting in a more uniform and thus more beneficial 


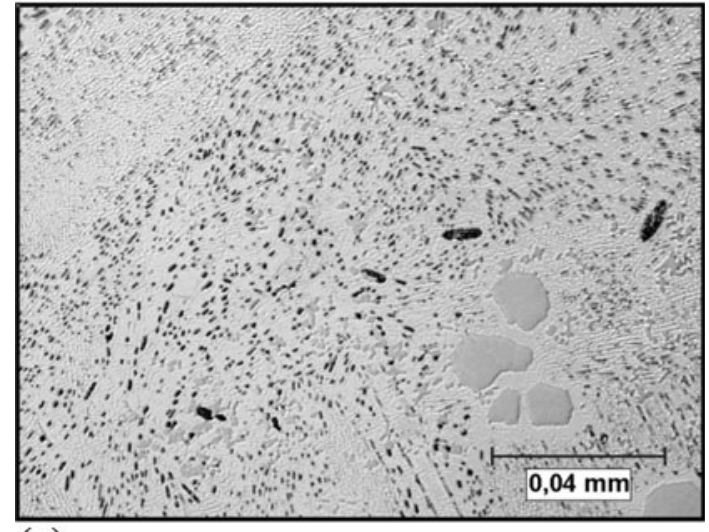

(a)

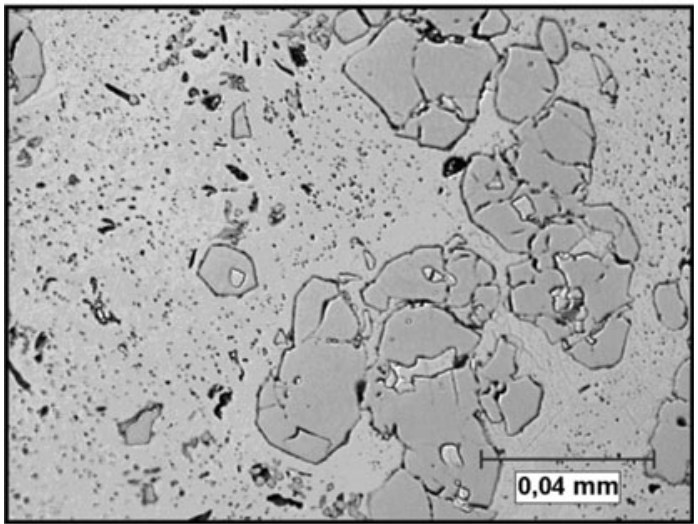

(b)

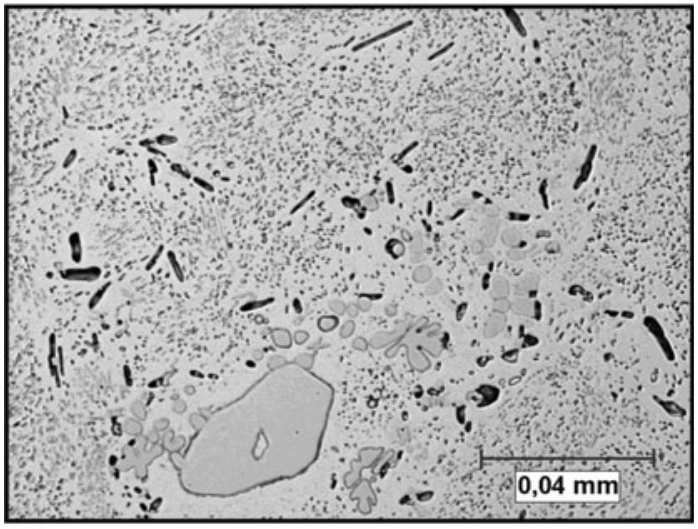

(c)

Fig. 7 Microstructure of heat-treated $\mathrm{SnZn} 13.5 \mathrm{Cu} 1$ alloy: $168 \mathrm{~h} / 50{ }^{\circ} \mathrm{C}$, (b) $42 \mathrm{~h} / 80{ }^{\circ} \mathrm{C}$, and (c) $24 \mathrm{~h} / 110{ }^{\circ} \mathrm{C}$

microstructure due to the reduced amount of second phase precipitates accompanied by the formation of more fine structure (Fig. 1a, c, 4a, b). For SnZn4.5 alloy, it takes place after annealing according to the two processing conditions of $168 \mathrm{~h} / 50{ }^{\circ} \mathrm{C}$ and $42 \mathrm{~h} / 80{ }^{\circ} \mathrm{C}$, while for SnZn13.5 alloy after heat treatment at the highest temperature $\left(24 \mathrm{~h} / 110^{\circ} \mathrm{C}\right)$. Despite the fact that the mechanical strength is improved in both the cases, the corresponding values are smaller than those obtained for the heattreated SnZn9 alloys. It may be considered as an additional evidence that for $\mathrm{Sn}-\mathrm{Zn}$ alloys containing 4.5-13.5 wt.\% Zn, the relative content of $\mathrm{Sn}$ - and $\mathrm{Zn}$-rich phases plays less important role than the microstructure homogeneity.

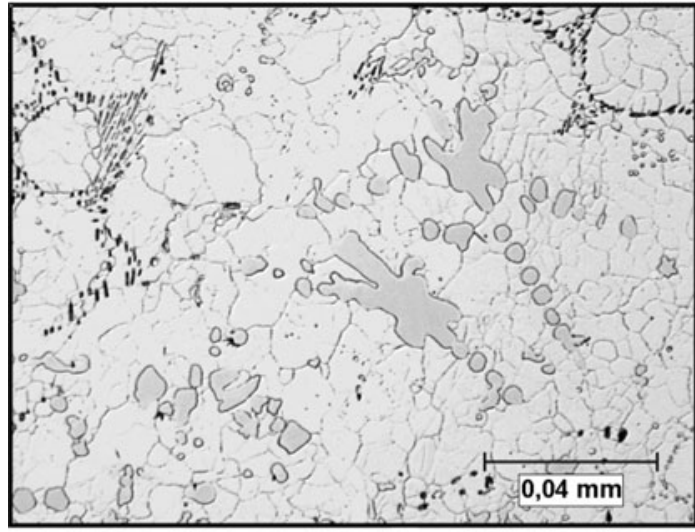

(a)

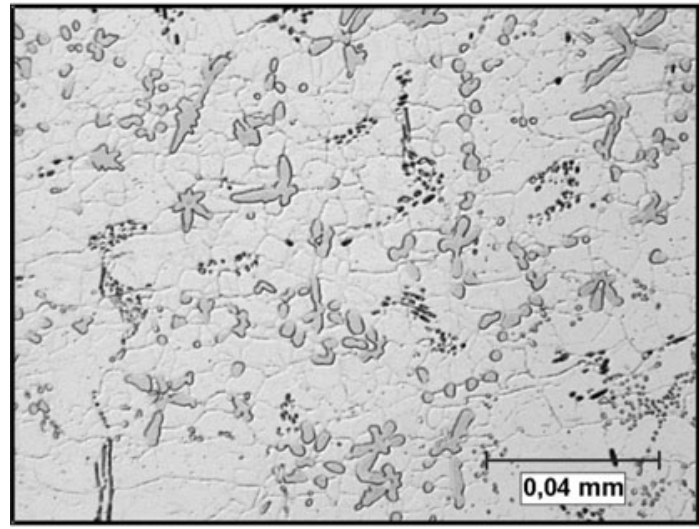

(b)

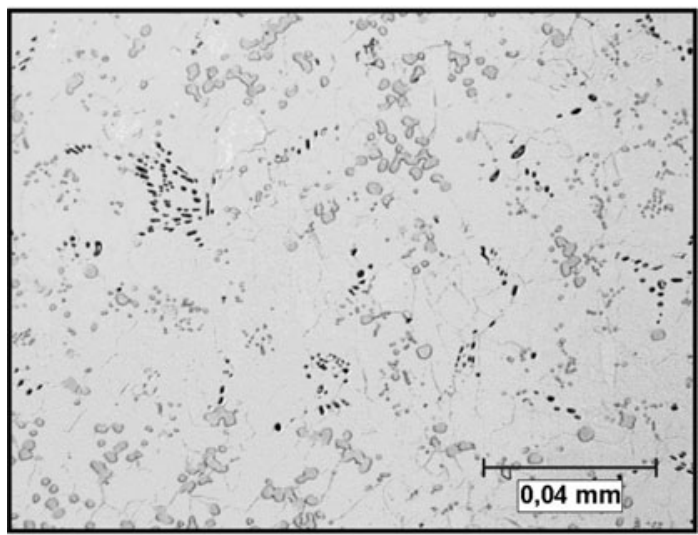

(c)

Fig. 8 Microstructure of heat-treated SnZn4.5Ag1 alloy: (a) $168 \mathrm{~h} /$ $50{ }^{\circ} \mathrm{C}$, (b) $42 \mathrm{~h} / 80{ }^{\circ} \mathrm{C}$, and (c) $24 \mathrm{~h} / 110{ }^{\circ} \mathrm{C}$

A comparison of experimental data for as-cast ternary alloys collected in Table 2 and 3 shows that for the same amount of $\mathrm{Zn}$, alloying with $1 \% \mathrm{Ag}$ has a beneficial effect on the improvement of mechanical properties of $\mathrm{Sn}-\mathrm{Zn}$-based alloys.

On the contrary, the addition of $1 \% \mathrm{Cu}$ causes their reduction. This effect can be contributed to a more beneficial microstructure of the Sn- $\mathrm{Zn}-\mathrm{Ag}$ alloys in which the $\mathrm{AgZn}_{3}$ precipitates are formed instead of the $\mathrm{Cu}_{5} \mathrm{Zn}_{8}$ ones observed in the $\mathrm{Sn}-\mathrm{Zn}-\mathrm{Cu}$ alloys. For ternary as-cast alloys, the best combination of mechanical properties was recorded in two alloys, i.e., 


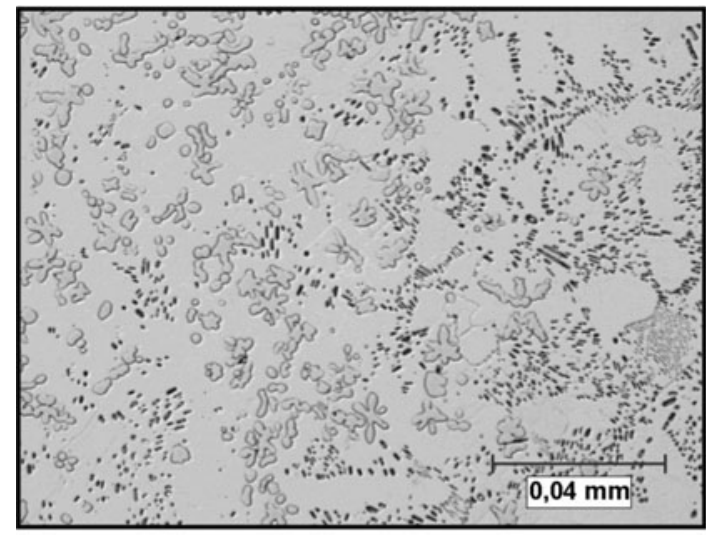

(a)

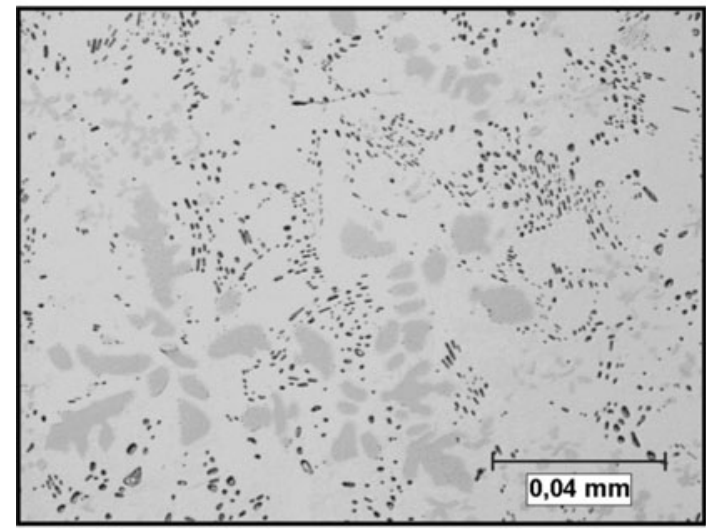

(b)

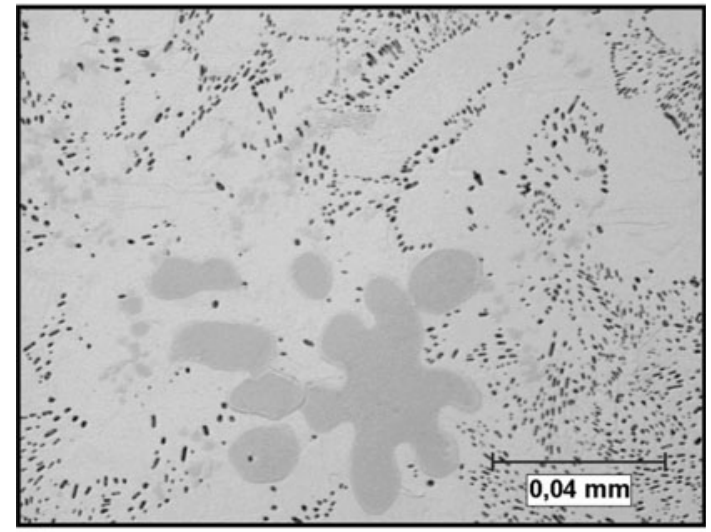

(c)

Fig. 9 Microstructure of heat-treated SnZn9Ag1 alloy: (a) $168 \mathrm{~h} /$ $50{ }^{\circ} \mathrm{C}$, (b) $42 \mathrm{~h} / 80{ }^{\circ} \mathrm{C}$, and (c) $24 \mathrm{~h} / 110^{\circ} \mathrm{C}$

SnZn13.5Cu1: $\quad R_{\mathrm{m}}-77 \mathrm{MPa}, \quad R_{0.05}-60 \mathrm{MPa}, \quad R_{0.2}-67$ MPa, $E-37 \mathrm{GPa}, A_{5}-38 \%, Z-54 \%$,

SnZn13.5Ag1: $\quad R_{\mathrm{m}}-99 \mathrm{MPa}, \quad R_{0.05}-80 \mathrm{MPa}, \quad R_{0.2}-91$ $\mathrm{MPa}, E-37 \mathrm{GPa}, A_{5}-13 \%, Z-22 \%$.

Heat treatment improves the mechanical strength $R_{\mathrm{m}}$ of $\mathrm{Sn}-\mathrm{Zn}$ $\mathrm{Cu}$ alloys, independently of the combination of time-temperature conditions used (Table 2). This positive change in material property is particularly evident in the $\mathrm{SnZn} 13.5 \mathrm{Cu} 1$ alloy after heat treatment at the lowest temperature $\left(168 \mathrm{~h} / 50{ }^{\circ} \mathrm{C}\right)$, showing the following values: $R_{\mathrm{m}}-89 \mathrm{MPa}, R_{0.05}-69 \mathrm{MPa}$, $R_{0.2}-78 \mathrm{MPa}, E-35 \mathrm{GPa}, A_{5}-52 \%, Z-57 \%$. Conversely,

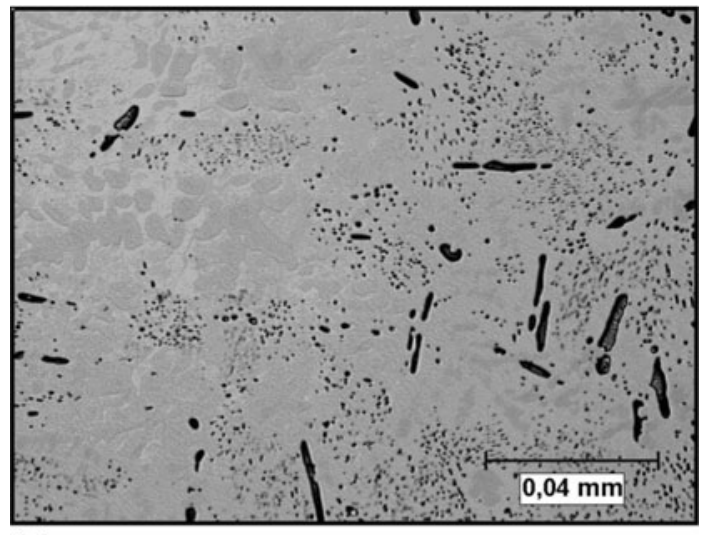

(a)

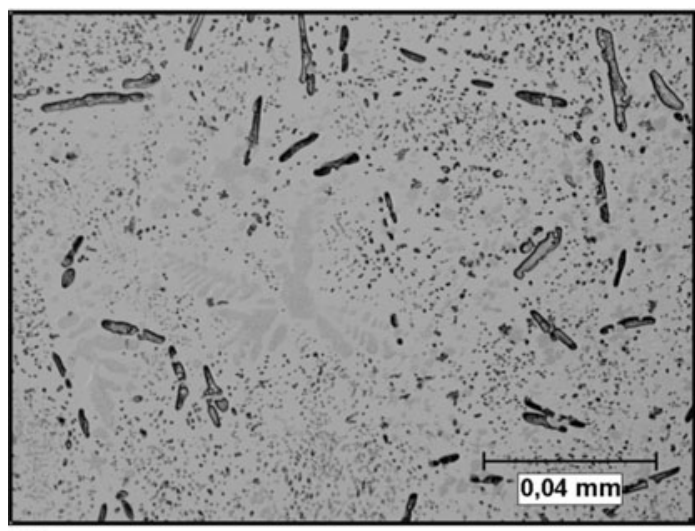

(b)

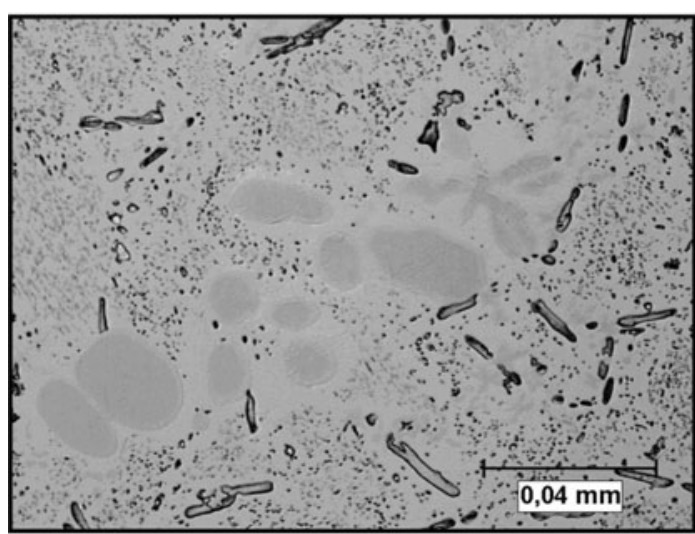

(c)

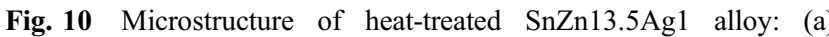
$168 \mathrm{~h} / 50{ }^{\circ} \mathrm{C}$, (b) $42 \mathrm{~h} / 80{ }^{\circ} \mathrm{C}$, and (c) $24 \mathrm{~h} / 110^{\circ} \mathrm{C}$

the heat-treated $\mathrm{Sn}-\mathrm{Zn}-\mathrm{Ag}$ alloys have lower $R_{\mathrm{m}}$ values, as compared to as-cast alloys (Table 3 ). The only exception is low Zn-containing SnZn4.5Ag1 alloy for which $R_{\mathrm{m}}$ increases significantly from $57 \mathrm{MPa}$ in as-cast state to $89 \mathrm{MPa}$ after the $168 \mathrm{~h} /$ $50{ }^{\circ} \mathrm{C}$ heat treatment. Moreover, as mentioned above, the same $R_{\mathrm{m}}$ value was also recorded for the $\mathrm{Sn}-\mathrm{Zn}-\mathrm{Cu}$ alloy containing 13.5 wt.\% $\mathrm{Zn}$ after the same annealing conditions, thus once again suggesting that the homogeneity of an alloy microstructure rather than the type of intermetallic compound formed and a relative content of the $\mathrm{Sn}$ - or $\mathrm{Zn}$-rich and IMC phases govern the mechanical behavior of the alloy. 
Table 1 Effect of heat treatment parameters on variations in mechanical parameters of binary $\mathrm{Sn}-\mathrm{Zn}$ alloys

\begin{tabular}{|c|c|c|c|c|c|c|}
\hline Processing parameters & $R_{0.05}, \mathrm{MPa}$ & $R_{0.2}, \mathrm{MPa}$ & $R_{\mathrm{m}}, \mathrm{MPa}$ & $E, \mathbf{G P a}$ & $A_{5}, \%$ & $Z, \%$ \\
\hline \multicolumn{7}{|l|}{ SnZn4.5 } \\
\hline As-cast & 46 & 51 & 61 & 26 & 55 & 84 \\
\hline $168 \mathrm{~h} / 50{ }^{\circ} \mathrm{C}$ & 53 & 59 & 66 & 26 & 65 & 84 \\
\hline $42 \mathrm{~h} / 80{ }^{\circ} \mathrm{C}$ & 52 & 59 & 66 & 26 & 49 & 74 \\
\hline $24 \mathrm{~h} / 110^{\circ} \mathrm{C}$ & 49 & 53 & 62 & 28 & 57 & 81 \\
\hline \multicolumn{7}{|l|}{ SnZn9 } \\
\hline As-cast & 72 & 79 & 88 & 39 & 41 & 84 \\
\hline $168 \mathrm{~h} / 50^{\circ} \mathrm{C}$ & 66 & 75 & 85 & 32 & 62 & 81 \\
\hline $42 \mathrm{~h} / 80{ }^{\circ} \mathrm{C}$ & 68 & 75 & 85 & 33 & 50 & 73 \\
\hline $24 \mathrm{~h} / 110^{\circ} \mathrm{C}$ & 65 & 72 & 81 & 32 & 55 & 81 \\
\hline \multicolumn{7}{|l|}{ SnZn13.5 } \\
\hline As-cast & 58 & 64 & 72 & 32 & 41 & 71 \\
\hline $168 \mathrm{~h} / 50^{\circ} \mathrm{C}$ & 56 & 63 & 72 & 28 & 59 & 78 \\
\hline $42 \mathrm{~h} / 80{ }^{\circ} \mathrm{C}$ & 57 & 64 & 74 & 27 & 49 & 67 \\
\hline $24 \mathrm{~h} / 110^{\circ} \mathrm{C}$ & 59 & 67 & 76 & 28 & 23 & 51 \\
\hline
\end{tabular}

All data represent mean values resulting from measurements of five samples

Table 2 Effect of heat treatment parameters on variations in mechanical parameters of ternary $\mathrm{Sn}-\mathrm{Zn}-\mathrm{Cu}$ alloys

\begin{tabular}{|c|c|c|c|c|c|c|}
\hline Processing parameters & $R_{0.05}, \mathrm{MPa}$ & $R_{0.2}, \mathrm{MPa}$ & $R_{\mathrm{m}}, \mathrm{MPa}$ & $E, \mathbf{G P a}$ & $A_{5}, \%$ & $Z, \%$ \\
\hline \multicolumn{7}{|l|}{$\mathrm{SnZn} 4.5 \mathrm{Cu} 1$} \\
\hline As-cast & 42 & 45 & 53 & 27 & 49 & 76 \\
\hline $168 \mathrm{~h} / 50{ }^{\circ} \mathrm{C}$ & 46 & 49 & 58 & 26 & 60 & 78 \\
\hline $42 \mathrm{~h} / 80{ }^{\circ} \mathrm{C}$ & 43 & 46 & 55 & 25 & 66 & 73 \\
\hline $24 \mathrm{~h} / 110^{\circ} \mathrm{C}$ & 45 & 49 & 58 & 25 & 59 & 74 \\
\hline \multicolumn{7}{|l|}{ SnZn9Cu1 } \\
\hline As-cast & 43 & 49 & 58 & 23 & 64 & 75 \\
\hline $168 \mathrm{~h} / 50{ }^{\circ} \mathrm{C}$ & 48 & 53 & 63 & 28 & 59 & 64 \\
\hline $42 \mathrm{~h} / 80{ }^{\circ} \mathrm{C}$ & 49 & 54 & 64 & 25 & 61 & 61 \\
\hline $24 \mathrm{~h} / 110^{\circ} \mathrm{C}$ & 49 & 55 & 65 & 24 & 58 & 67 \\
\hline \multicolumn{7}{|l|}{$\mathrm{SnZn13.5Cu1}$} \\
\hline As-cast & 60 & 67 & 77 & 37 & 38 & 54 \\
\hline $168 \mathrm{~h} / 50^{\circ} \mathrm{C}$ & 69 & 78 & 89 & 35 & 52 & 58 \\
\hline $42 \mathrm{~h} / 80{ }^{\circ} \mathrm{C}$ & 69 & 78 & 88 & 34 & 69 & 68 \\
\hline $24 \mathrm{~h} / 110^{\circ} \mathrm{C}$ & 63 & 72 & 82 & 32 & 51 & 58 \\
\hline
\end{tabular}

All data represent mean values resulting from measurements of five samples

Table 3 Effect of heat treatment parameters on variations in mechanical parameters of ternary $\mathrm{Sn}-\mathrm{Zn}$-Ag alloys

\begin{tabular}{|c|c|c|c|c|c|c|}
\hline Processing parameters & $\boldsymbol{R}_{\mathbf{0 . 0 5}}, \mathrm{MPa}$ & $\boldsymbol{R}_{0.2}, \mathrm{MPa}$ & $\boldsymbol{R}_{\mathrm{m}}, \mathrm{MPa}$ & $E, \mathbf{G P a}$ & $A_{5}, \%$ & $Z, \%$ \\
\hline \multicolumn{7}{|l|}{ SnZn4.5Ag1 } \\
\hline As-cast & 45 & 49 & 57 & 26 & 34 & 43 \\
\hline $168 \mathrm{~h} / 50^{\circ} \mathrm{C}$ & 69 & 78 & 89 & 35 & 52 & 58 \\
\hline $42 \mathrm{~h} / 80{ }^{\circ} \mathrm{C}$ & 42 & 46 & 53 & 28 & 48 & 76 \\
\hline $24 \mathrm{~h} / 110^{\circ} \mathrm{C}$ & 41 & 46 & 53 & 25 & 26 & 58 \\
\hline \multicolumn{7}{|l|}{ SnZn9Ag1 } \\
\hline As-cast & 57 & 64 & 76 & 29 & 51 & 59 \\
\hline $168 \mathrm{~h} / 50^{\circ} \mathrm{C}$ & 45 & 51 & 60 & 24 & 27 & 55 \\
\hline $42 \mathrm{~h} / 80^{\circ} \mathrm{C}$ & 46 & 51 & 59 & 27 & 23 & 40 \\
\hline $24 \mathrm{~h} / 110^{\circ} \mathrm{C}$ & 49 & 55 & 65 & 27 & 21 & 58 \\
\hline \multicolumn{7}{|l|}{ SnZn13.5Ag1 } \\
\hline As-cast & 80 & 91 & 99 & 37 & 13 & 22 \\
\hline $168 \mathrm{~h} / 50{ }^{\circ} \mathrm{C}$ & 56 & 63 & 69 & 28 & 15 & 40 \\
\hline $42 \mathrm{~h} / 80^{\circ} \mathrm{C}$ & 65 & 72 & 77 & 36 & 27 & 53 \\
\hline $24 \mathrm{~h} / 110^{\circ} \mathrm{C}$ & 62 & 67 & 74 & 33 & 16 & 42 \\
\hline
\end{tabular}

All data represent mean values resulting from measurements of five samples 
Comparison of the results of mechanical tests in this study to those from available literature data obtained under comparable testing conditions on as-cast alloys (Ref 9) shows that the mechanical strength of $\mathrm{Sn}-\mathrm{Pb}$ solders is in a range of $47-$ $67 \mathrm{MPa}$, depending on the alloy chemical composition. Its highest value corresponds to the $\mathrm{SnPb} 37$ alloy and is only slightly higher than mechanical strength of the as-cast SnZn4.5 alloy of this study $(61 \mathrm{MPa})$. However, after heat treatment at all the selected time-temperature conditions, both the alloys have the same mechanical strength of $67 \mathrm{MPa}$.

All the remaining examined alloys of $\mathrm{Sn}-\mathrm{Zn}, \mathrm{Sn}-\mathrm{Zn}-\mathrm{Cu}$, and $\mathrm{Sn}-\mathrm{Zn}$-Ag systems show better mechanical strength than common $\mathrm{Sn}-\mathrm{Pb}$ alloys. The alloys particularly competitive to leaded solders are those of ternary systems containing $13.5 \mathrm{wt} . \% \mathrm{Zn}$ and either $1 \mathrm{wt} . \% \mathrm{Cu}$ or $\mathrm{Ag}$ showing much higher tensile strength, both in ascast (SnZn13.5Cu1-77 MPa; SnZn13.5Ag1—99 MPa) and heat-treated (SnZn13.5Cu1-82-29 MPa; SnZn13.5Ag1-69$77 \mathrm{MPa}$ ) states.

Despite the fact that the literature data on mechanical strength of $\mathrm{Pb}$-free solders of SAC family ( $\mathrm{Sn}-\mathrm{Ag}-\mathrm{Cu}$ system) are highly scattered, depending on the alloy chemical composition and testing conditions (Ref 10), one may conclude that their values, particularly for tensile strength, are below those measured in this study for Sn-Zn-based alloys. The most representative results if tensile strength of SAC solders are as follows (Ref 10): SnAg3.8Cu0.7-39.6-56 MPa; SnAg3.5$\mathrm{Cu} 0.7$-58.5 MPa; SnAg3.2Cu0.8 - 30 MPa; SnAg3$\mathrm{Cu} 0.5$ - 41.8-50.6 MPa; $\mathrm{SnAg} 4 \mathrm{Cu} 0.5-38 \mathrm{MPa}$ for as-cast and $34-314 \mathrm{MPa}$ after aging at $125^{\circ} \mathrm{C}$ for $24-250 \mathrm{~h}$, respectively; $\mathrm{SnAg} 2 \mathrm{Cu} 1.5-39 \mathrm{MPa}$ for as-cast and 30-26 MPa after aging at $125^{\circ} \mathrm{C}$ for $24-250 \mathrm{~h}$, respectively; SnAg3.5$\mathrm{Cu} 05-47.8 \mathrm{MPa}$.

\section{Conclusions}

(1) Among the examined as-cast binary Sn-Zn alloys, the best combination of mechanical characteristics was obtained for the SnZn9 alloy of near-eutectic composition and beneficial microstructure, i.e., eutectic grains of fine fibrous structure and a negligible amount of small needle-like Zn-rich precipitates. This beneficial uniform microstructure is responsible for high mechanical properties of as-cast SnZn9 alloy with slight improvement in its mechanical strength after heat treatment.

(2) For binary alloys, a significant effect of heat treatment parameters on mechanical properties was noted for the SnZn4.5 and SnZn13.5 alloys as a consequence of the advantageous change to a more uniform microstructure.

(3) Introduction of $1 \mathrm{wt} . \% \mathrm{Cu}$ almost completely eliminates the formation of $\mathrm{Zn}$-rich needle-like precipitates in the as-cast alloys containing 4.5-13.5 wt.\% Zn, conversely to those with $1 \mathrm{wt} . \% \mathrm{Ag}$.

(4) For as-cast $\mathrm{Sn}-\mathrm{Zn}-\mathrm{Cu}$ and $\mathrm{Sn}-\mathrm{Zn}-\mathrm{Ag}$ alloys, the best

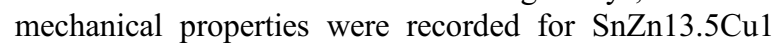
and SnZn13.5Ag1 compositions showing in all the examined alloys the most homogeneous structure composed of eutectic grains with dispersed primary precipitates of $\mathrm{AgZn}_{3}$ and $\mathrm{Cu}_{5} \mathrm{Zn}_{8}$, respectively.
(5) Beneficial microstructural changes also take place during annealing of the $\mathrm{Sn}-\mathrm{Zn}-\mathrm{Cu}$ alloys resulting in the improvement of their mechanical strength, independently of a combination of the time-temperature conditions used. Conversely, the heat-treated SnZn9Ag1 and SnZn13.5Ag1 alloys have slightly lower $R_{\mathrm{m}}$ values, as compared to as-cast alloys because their microstructure becomes less uniform.

(6) All the selected Sn-Zn-based alloys examined in this study have attractive combination of mechanical characteristics, especially tensile strength, having values higher than that of the common leaded solders and their substitutes of $\mathrm{Pb}$-free $\mathrm{SAC}$ family. The results obtained demonstrate that the Sn-Zn-based alloys present competitive $\mathrm{Pb}$-free solder candidates for high-temperature applications.

\section{Acknowledgment}

The research was carried out in the framework of the EU COST ACTION MP0602 with financial support from the Ministry of Science and Higher Education of Poland.

\section{Open Access}

This article is distributed under the terms of the Creative Commons Attribution License which permits any use, distribution, and reproduction in any medium, provided the original author(s) and the source are credited.

\section{References}

1. K.J. Puttlitz and K.A. Stalter, Ed., Handbook of Lead-Free Solder Technology for Microelectronic Assemblies, CRC Press, Boca Raton, 2004

2. N. Sobczak, K. Pietrzak, A. Kudyba, A. Wojciechowski, J. Sobczak, and R. Nowak, Atlas of Microstructures of Solder Alloys and Solder/ Metal Interfaces. Part I: Optical Microscopy, Motor Transport Institute-Foundry Research Institute, Poland, 2009

3. N. Sobczak, A. Kudyba, R. Nowak, W. Radziwill, and K. Pietrzak, Factors Affecting Wettability and Bond Strength of Solder Joint Couples, Pure Appl. Chem., 2007, 79(10), p 1755-1769

4. F. Abd El-Salam, R.H. Nada, and A.M. Abd El-Khalek, Effect of Cu Addition on the Structural and Mechanical Properties of Sn-Zn Alloy, Mater. Sci. Eng. A, 2007, 448, p 171-176

5. K.-I. Chen and K.-L. Lin, The Microstructures and Mechanical Properties of the Sn-Zn-Ag-Al-Ga Solder Alloys - the Effect of Ag, J. Electron. Mater., 2002, 31(8), p 861-867

6. J.M. Sung, F. Lan, and L.H. Chen, Microstructural Features and Vibration Fracture Behavior of Sn-Zn-Ag Solder Alloys, Mater. Sci., 2002, C, p 276-281

7. F. Vnuk, M. Sahoo, D. Baragar, and R.W. Smith, Mechanical Properties of the Sn-Zn Eutectic Alloys, J. Mater. Sci., 2011, 15(10), p 2573-2583

8. A.A. El-Daly, Y. Swilem, M.H. Makled, M.G. El-Shaaraway, and A.M. Abdraboh, Thermal and Mechanical Properties of Sn-Zn-Bi Lead-Free Solder Alloys, J. Alloys Compd., 2009, 484, p 134-142

9. Henkel Loctite Adhesives Ltd, Technical Data Sheet, Properties of Alloys of Multicore Solder Wires, August 2007, http://tds.loctite.com/ tds5/docs/M-POFA-EN.PDF

10. ELFNET COST Action 531-Handbook of Properties of SAC Solders and Joints, Vol. 2, COST Office, 2008 